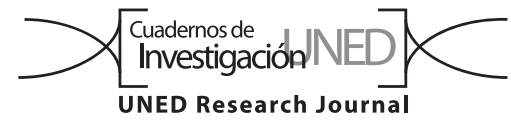

\title{
NOTE
}

\section{Feeding behavior of Costa Rican velvet worms: food hiding, parental feeding investment and ontogenetic diet shift (Onychophora: Peripatidae)}

\author{
José Pablo Barquero-González', Álvaro Vega-Hidalgo \& Julián Monge-Nájera² \\ 1. Universidad Nacional, Laboratorio de Genética Evolutiva, Escuela de Ciencias Biológicas, Heredia, Costa Rica; jopbgon@gmail.com \\ 2. Universidad Estatal a Distancia, Vicerrectoría de Investigación, Laboratorio de Ecología Urbana, 2050 San José, Costa Rica; \\ julianmonge@gmail.com
}

Received 21-VIII-2018 • Corrected 24-IX-2018 • Accepted 22-X-2018

\begin{abstract}
We report, for the first time in onychophorans, food hiding, parental feeding investment and an ontogenetic diet shift two weeks after birth: from the parent's adhesive used to capture prey, to the prey itself.
\end{abstract}

Key words: feeding behavior, Peripatidae, Panarthropoda behavior, undescribed Costa Rican onychophorans, parental investment.
RESUMEN: “Comportamiento alimentario de los gusanos de terciopelo costarricenses: ocultamiento de alimentos, inversión materna y cambio ontogénico de dieta (Onychophora: Peripatidae)". Informamos, por primera vez en onicóforos, de ocultamiento de alimentos, inversión parental alimentaria y cambio ontogénico de alimento. En las primeras dos semanas de vida, los jóvenes se alimentan exclusivamente de la goma usada por los progenitores para capturar las presas, y luego cambian a alimentarse de las presas en sí.

Palabras clave: comportamiento alimentario, Peripatidae, comportamiento de Panarthropoda, onicóforos costarricenses no descritos, inversión parental.
The basic feeding behavior of onychophorans has been known for over a century: they capture prey with aid of an adhesive ejected by oral papillae, bite into the exoskeleton, and ingest the partially digested tissues (Moseley, 1874). The adhesive takes about three weeks to be replenished and is thought to be metabolically valuable, since it is re-ingested after hunting (Read \& Hughes, 1987). In the species Euperipatoides rowelli Reid, 1996, prey are hunted collectively and consumed in hierarchical order (Reinhard \& Rowell, 2005). Nevertheless, the feeding behavior has only been studied in adults and in a few of over 200 named species (Read \& Hughes, 1987; Reinhard \& Rowell, 2005; Mayer, et al., 2015). Here we report, for the first time in the phylum Onychophora, three behaviors: food hiding, parental feeding investment, and ontogenetic food shift.

From December 2016 to January 2018, individuals from eight morph-species of onychophorans from the sub-family Neopatida were housed in terraria (collection permit codes: SINAC-SE-CUSBSE-PI-R-133-2016 and SINAC-SE-CUSBSE-PI-R-015-2017). Details appear in Table 1 and in previous publications (Barquero-González, et al., 2016, and Sosa-Bartuano, Monge-Nájera, \& MoreraBrenes, 2018). For terraria we used plastic containers: $45 \times 29 \times 39 \mathrm{~cm}$ for the Gandoca species and $33 \times 20 \times 12 \mathrm{~cm}$ for the other species. Each terrarium had dirt, mosses, twigs and bark; and 1-3 females with their newborns (rarely, also one male). Settings: natural light; $99 \%$ constant humidity; $25-27^{\circ} \mathrm{C}$ at day and $22-23^{\circ} \mathrm{C}$ at night (Inkbird Thermometer \& Hygrometer ITH-10).

They were fed once a week with live or freshly killed domestic crickets introduced from 19:00 to 20:00h. Prey not consumed after $12 \mathrm{~h}$ was removed to prevent contamination.

The onychophorans hid food in burrows, and under moss or bark: small prey was dragged, while pieces of 
TABLE 1

Details on individuals used for this report, and number of prey according to which prey part was consumed first. New morpho-species are indicated with *

\begin{tabular}{|c|c|c|c|c|c|}
\hline Species & $\begin{array}{l}\text { Time kept } \\
\text { (months) }\end{array}$ & $\begin{array}{l}\text { Adult individuals } \\
\text { kept }\end{array}$ & $\begin{array}{l}\text { Head first } \\
\text { feeding }\end{array}$ & $\begin{array}{l}\text { Thorax first } \\
\text { feeding }\end{array}$ & $\begin{array}{l}\text { Abdomen } \\
\text { first feeding }\end{array}$ \\
\hline Agujas Purple Brown Onychophoran & 5 & 2 (plus 1 offspring) & 2 & 2 & 6 \\
\hline Batán Burgundy Brown Onychophoran & 1 & 3 (plus 1 offspring) & 3 & 0 & 0 \\
\hline Epiperipatus biolleyi & 1 & 5 (plus 7 offspring) & 4 & 0 & 0 \\
\hline Fortuna Burgundy Brown Onychophoran* & 2 & 2 (plus 1 offspring) & 4 & 2 & 0 \\
\hline Gandoca Blue Onychophoran & 5 & 1 (plus 7 offspring) & 3 & 5 & 0 \\
\hline Peripatus solorzanoi & 5 & 3 (plus 5 offspring) & 6 & 2 & 0 \\
\hline Quesada Burgundy Brown Onychophoran & 5 & 3 (plus 2 offspring) & 8 & 1 & 0 \\
\hline San Vito Collared Onychophoran* & 2 & 2 (plus 3 offspring) & 1 & 0 & 4 \\
\hline Sarapiquí Yellow Brown Onychophoran & 1 & 2 (plus 1 offspring) & 2 & 0 & 0 \\
\hline
\end{tabular}

larger prey were carried in the mouth (Fig. 1, behavior seen three times in the San Carlos species, five in Drake and two in Fortuna). Hiding unfinished food protects it from predators and scavengers, and has evolved independently in many species, from invertebrates to mammals (Estes, 1991; Lawrence \& Newton, 1995). Food hiding may be particularly important in onychophorans because they hunt only a few times per month and are slow to process food (Read \& Hughes, 1987).
Unlike E. rowelli, which dispute food (Reinhard \& Rowell, 2005), these species shared the prey (Fig. 1D), perhaps because specimens found together tend to be relatives (see Monge-Nájera, 1995).

Specimens from Gandoca started the feeding process on the prey's thorax (Fig. 2A); while those from Batán, Quesada, Sarapiquí and Fortuna, as well as Epiperipatus biolleyi and Peripatus solorzanoi, started feeding by the prey`s head (Fig. 2B); the Agujas and San Vito species
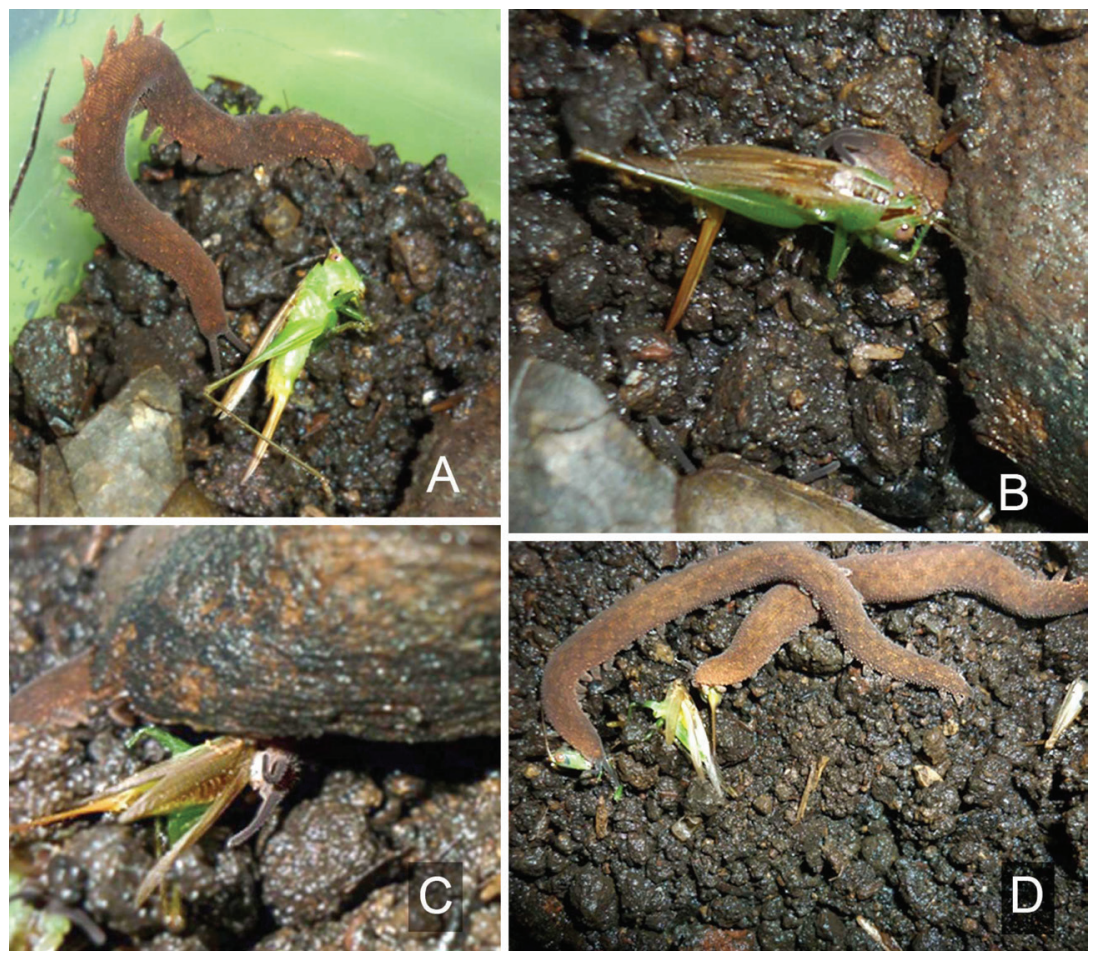

Fig. 1. Quesada Burgundy Brown Onychophoran morph-species feeding sequence includes prey inspection (A: adult female inspecting a dead cricket that we placed in the terrarium), and hiding unfinished prey (she used her mandibles to drag it under a piece of wood, B-C). Adults can feed simultaneously, without aggression, on different prey parts (D). 

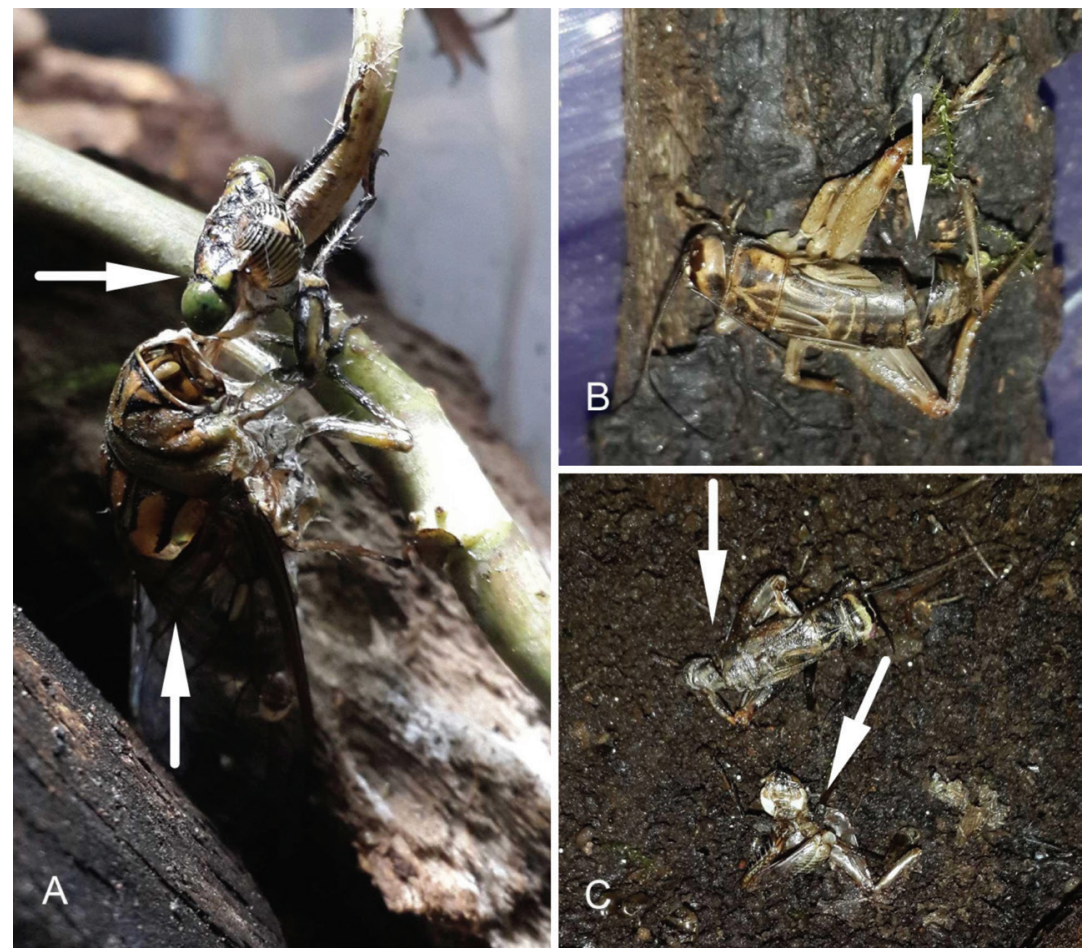

Fig. 2. Some onychophorans start feeding by removing the head (e.g. P. solorzanoi, A: arrow indicates cicada head separated from thorax by the onychophoran), others by opening the abdomen (San Vito Onychophoran, B: arrow indicates gap in the abdomen), and others by separating the thorax (Fortuna Onychophoran, C: arrows indicate thorax cut in two).

started by the abdominal region (Fig. 2C). The cause of this variation is ignored.

During their first two weeks of life, the young only fed on the adhesive threads used to capture prey by the adults, rather than on the prey itself, apparently a form of parental feeding investment. After those two weeks, there is an ontological diet shift and adult females of the Gandocan morph-species and P. solorzanoi, shared the prey with their offspring (or the young found prey by themselves).

An ontological diet shift is present in a variety of organisms, and results from strong selection to optimize the use of limited resources (Ten Brink \& de Roos, 2017). To future researchers, we propose two hypotheses, that (1) the young feed on adhesive because it is a better food than the prey; or (2) that initially they cannot process prey because their digestive system is immature. Both causes are documented in other animals (Blackburn, Hayssen \& Murphy, 1989; Langer, 2002) and are based on our observations of glue consumption even when prey was available to feed on.

Ethical, conflict of interest and financial statements: the authors declare that they have fully complied with all pertinent ethical and legal requirements, both during the study and in the production of the manuscript; that there are no conflicts of interest of any kind; that all financial sources are fully and clearly stated in the acknowledgements section; and that they fully agree with the final edited version of the article. A signed document has been filed in the journal archives.

\section{ACKNOWLEDGMENTS}

We thank William Eberhard for advice, Bernal Morera Brenes for guidance, Diego Monge Villegas for the image editing, and three anonymous reviewers for useful comments.

\section{REFERENCES}

Barquero-González, J.P., Acosta-Chaves, V.J., Sotela, M.L., Villalobos Brenes, F., \& Morera-Brenes, B. (2016). Photographic evidence of undescribed species of velvet worms (Onychophora: Peripatidae) from Costa Rica. UNED Research Journal, 8(2), 139-147.

Blackburn, D.G., Hayssen, V., \& Murphy, C.J. (1989). The origins of lactation and the evolution of milk: a review with new 
hypotheses. Mammal Review, 19(1), 1-26. DOI: 10.1111/ j.1365-2907.1989.tb00398.x

Estes, R. (1991). The behavior guide to African mammals: including hoofed mammals, carnivores, primates. California, U.S.A.: University of California Press.

Langer, P. (2002). The digestive tract and life history of smaII mammals. Mammal Review 32, 2, 107-131. DOI: 10.1046/j.1365-2907.2002.00101.x

Lawrence, J.F., \& Newton, A.F., Jr. (1995). Families and subfamilies of Coleoptera (with selected genera, notes, references and data on family-group names). In Pakaluk, J. \& Slipinski S. (Eds.), Biology, phylogeny and classification of Coleoptera. Warszawa, Poland: Muzeum i Instytut Zoologii PAN.

Mayer, G., Oliveira, I.S., Baer, A., Hammel, J.U., Gallant, J., \& Hochberg, R. (2015). Capture of prey, feeding, and functional anatomy of the jaws in velvet worms (Onychophora). Integrative and Comparative Biology, 55(2), 217-227. DOI: 10.1093/icb/icv004

Monge-Nájera, J. (1995). Phylogeny, biogeography and reproductive trends in the Onychophora. Zoological Journal of the Linnean Society, 114(1), 21-60. DOI: 10.1111/ j.1096-3642.1995.tb00111.x
Moseley, H.N. (1874). I. On the structure and development of Peripatus capensis. Proceedings of the Royal Society of London, 22(148-155), 344-350. DOI: 10.1098/ rstl.1874.0022

Read, V.S.J., \& Hughes, R.N. (1987). Feeding behaviour and prey choice in Macroperipatus torquatus (Onychophora). Proceedings of the Royal Society of London B, 230(1261), 483-506. DOI: 10.1098/rspb.1987.0030

Reinhard, J., \& Rowell, D.M. (2005). Social behaviour in an Australian velvet worm, Euperipatoides rowelli (Onychophora: Peripatopsidae). Journal of Zoology, 267(1), 1-7. DOI: 10.1017/S0952836905007090

Sosa-Bartuano, Á., Monge-Nájera, J., \& Morera-Brenes, B. (2018). A proposed solution to the species problem in velvet worm conservation (Onychophora). UNED Research Journal, 10(1), 204-208. DOI: 10.22458/urj.v10i1.2027

Ten Brink, H., \& de Roos, A.M. (2017). A Parent-Offspring Trade-Off Limits the Evolution of an Ontogenetic Niche Shift. The American Naturalist, 190(1), 45-60. DOI: $10.1086 / 692066$

\section{EDITED BY CAROLINA SEAS}

